\title{
Adalimumab treatment in patients with rheumatoid arthritis, ankylosing spondylitis and psoriatic arthritis in therapeutic programmes - personal experience
}

\author{
Doświadczenia własne $w$ leczeniu adalimumabem chorych na reumatoidalne \\ zapalenie stawów, zesztywniające zapalenie stawów kręgosłupa i łuszczycowe \\ zapalenie stawów $w$ programach terapeutycznych
}

\author{
Bożena Targońska-Stępniak, Maria Majdan, Renata Seweryn, Zofia Kiełbik \\ Chair and Department of Rheumatology and Connective Tissue Diseases, Medical University of Lublin \\ Katedra i Klinika Reumatologii i Układowych Chorób Tkanki Łącznej Uniwersytetu Medycznego w Lublinie
}

Key words: rheumatoid arthritis, ankylosing spondylitis, psoriatic arthritis, biological drugs.

Słowa kluczowe: reumatoidalne zapalenie stawów, zesztywniające zapalenie stawów kręgosłupa, łuszczycowe zapalenie stawów, leki biologiczne.

\section{Sum mary}

The objective of the study was to investigate the effects and safety of adalimumab (ADA) therapy in the national therapeutic programme, in patients with rheumatoid arthritis (RA), ankylosing spondylitis (AS) and psoriatic arthritis (PSA).

Material and methods: The process of ADA therapy was analysed in 41 patients (24 RA, 11 AS, 6 PSA). Patients were qualified, according to the rules of the therapeutic programme of the National Health Service, due to high disease activity, despite previous treatment. Monitoring of patients was performed according to the requirements of the therapeutic programme. ADA was given subcutaneously $40 \mathrm{mg}$ every other week.

Results: In the RA group, an adequate response to therapy was observed in 13 patients (54.2\%): remission in 8 (33.3\%) and low disease activity in 5 (20.9\%), which continued in 5 patients after ADA cessation, for a mean of 4.5 months. Primary inefficacy after 3 months of therapy (lack of adequate response) was observed in $4(16.7 \%)$, after 6 months of therapy (lack of remission/low disease activity) in 10 (41.7\%). During remission/low activity period, exacerbation of RA was observed in 6/13 patients; in 2/13 secondary inefficacy was observed. In the AS group, in 1 patient (9.1\%) primary inefficacy was observed. In 10 (90.9\%) low disease activity was achieved in 9 patients (90.9\%), which continued for a mean of 5.4 months. During the improvement period, after cessation of ADA, 8/10 patients experienced exacerbation; secondary inefficacy was observed in $1 / 10$ patients. In the PsA group, low disease activity was achieved in 5 patients (83.3\%) during ADA administration; in 1 (16.7\%) primary inefficacy was observed. In

\section{Streszczenie}

Celem pracy była ocena skuteczności i bezpieczeństwa leczenia adalimumabem (ADA), w ramach programu terapeutycznego NFZ, chorych na reumatoidalne zapalenie stawów (RZS), zesztywniające zapalenie stawów kręgosłupa (ZZSK) i łuszczycowe zapalenie stawów (tZS). Materiał i metody: Przebieg leczenia ADA analizowano w grupie 41 chorych (24 na RZS, 11 na ZZSK, 6 na ŁZS). Do leczenia kwalifikowano chorych wg zasad programu terapeutycznego NFZ, z dużą aktywnością choroby, pomimo dotychczas stosowanego leczenia. Adalimumab podawano podskórnie $w$ dawce $40 \mathrm{mg}$ raz na 2 tygodnie.

Wyniki: Wśród chorych na RZS u 13 (54,2\%) obserwowano adekwatną odpowiedź na leczenie: remisję u 8 osób (33,3\%) i małą aktywność u 5 (20,9\%), która po przerwaniu leczenia ADA utrzymywała się u 5 chorych przez średnio 4,5 miesiąca. Nieskuteczność pierwotną stwierdzono po 3 miesiącach (brak adekwatnej odpowiedzi) $u 4$ chorych (16,7\%), po 6 miesiącach (brak remisji/małej aktywności) u 10 osób (41,7\%). W okresie remisji/małej aktywności u 6 z 13 chorych obserwowano zaostrzenie RZS; u 2 z 13 chorych wystąpiła nieskuteczność wtórna. Wśród chorych na ZZSK u 1 chorego $(9,1 \%)$ obserwowano nieskuteczność pierwotną. $\bigcup 10$ osób (90,9\%) uzyskano małą aktywność choroby, która po przerwaniu leczenia ADA utrzymywała się przez średnio 5,4 miesiąca. W okresie poprawy, po przerwaniu terapii, u 8 z 10 chorych nastąpiło zaostrzenie; nieskuteczność wtórna wystąpiła u 1 z 10 chorych. $U$ chorych na ŁZS małą aktywność choroby uzyskano u 5 chorych (83,3\%), utrzymującą się podczas podawania leku; nieskuteczność pierwotną u 1 chorego (16,7\%). W całej grupie 41 chorych leczonych ADA u 17 (41,5\%) wystąpity objawy niepożąda-

\section{Address for correspondence:}

dr hab. n. med. Bożena Targońska-Stępniak, Katedra i Klinika Reumatologii i Układowych Chorób Tkanki Łącznej UM, ul. Jaczewskiego 8 , 20-950 Lublin, tel. +48 8172447 90; fax +48 8174251 03, e-mail: bozena.stepniak@am.lublin.pl 
all treated patients, adverse events were noted in 17/41 (41.5\%): infections (urinary, respiratory tract, viral), injection site reactions. They resulted in cessation of ADA therapy in 5 patients (4 RA patients and 1 AS patient). The number of adequate responses to ADA treatment was statistically significantly higher in AS than in RA patients $(p=0.04)$ Conclusions: Treatment of ADA is a safe and effective form of therapy in patients with RA, AS and PsA, those with persistent high dis ease activity and non-responders to previous therapy.

\section{Introduction and aims of the study}

Adalimumab (ADA) is a fully human monoclonal antibody directed against the tumour necrosis factor (TNF), registered for the treatment of rheumatoid arthritis (RA), psoriatic arthritis (PSA) and other immune-dependent inflammatory disorders including, among others, ankylosing spondylitis (AS) [1-3].

Randomized studies and clinical observations have demonstrated the effectiveness of ADA treatment in patients with RA with persistently high disease activity despite classic disease-modifying anti-rheumatic drug (DMARD) therapy [4, 5]. Beneficial effects have also been observed in patients who had received prior treatment with another anti-TNF agent, and who developed intolerance or secondary loss of efficacy to the earlier treatment, particularly in cases where loss of response was the result of production of antibodies directed against this medication $[6,7]$. Combining ADA therapy with methotrexate (MTX) is particularly indicated, since this produces superior clinical effects and halts radiological progression [8]. The efficacy of treatment with ADA has also been confirmed in patients with AS [9, 10] and PSA [11], including patients who had undergone prior treatment with other anti-TNF agents [12]

The results of anti-TNF therapy conducted in the everyday clinical practice setting have been presented in isolated reports; in addition to compliance with indications regarding arthritis treatment this entailed administering pharmacotherapy for a variety of concomitant diseases as well as modifying treatment to fulfil conditions imposed by the payer $[13,14]$.

The aim of the study was to analyse the effects and safety of treating patients with RA, AS and PSA using adalimumab, administered in a Polish National Health Fund ( $\mathrm{Na}$ rodowy Fundusz Zdrowia - NFZ) therapeutic programme, conducted in the Department of Rheumatology and Connective Tissue Diseases of the Medical University of Lublin (Klinika Reumatologii i Układowych Chorób Tkanki tącznej UM w Lublinie).

\section{Material and methods}

The study involved 41 patients (24 patients with RA, 11 with AS, and 6 with PSA), treated with ADA in NFZ therapeutic programmes in the years 2009-2012 in the ne: infekcje dróg moczowych, oddechowych, nawracające infekcje wirusowe, zmiany skórne. Objawy te były przyczyną przerwania leczenia u 5 chorych ( 4 chorych na RZS i 1 chory na ZZSK). Liczba adekwatnych odpowiedzi na leczenie ADA była statystycznie istotnie większa u chorych na ZZSK niż RZS ( $p=0,04)$.

Wnioski: Leczenie ADA jest skuteczną i bezpieczną formą terapii u chorych na RZS, ZZSK i ŁZS, z utrzymującą się dużą aktywnością choroby oraz niereagujących na dotychczasową terapię.

Department of Rheumatology and Connective Tissue Diseases of the Medical University of Lublin. One patient with RA had been receiving ADA therapy since 2005, initially as a non-standard treatment. Rheumatoid arthritis was diagnosed based on 1987 ACR (American College of Rheumatology) classification criteria. [15], AS based on modified New York criteria [16] and PSA was diagnosed based on the CASPAR criteria [17]

In the course of subsequent appointments, patients with RA underwent physical evaluation, which involved assessing the number of tender and swollen joints (for 28 joints), the severity of pain and disease activity on a visual analogue scale (VAS). RA activity was assessed based on the Disease Activity Score of 28 joints (Disease Activity Score 28, DAS28), along with the three above-mentioned parameters and erythrocyte sedimentation rate (ESR). Disease remission was defined as DAS28 $<2.6$, low disease activity as $\geq 2.6$ DAS $28 \leq 3.2$. In patients with AS, disease activity was assessed based on spinal pain VAS and the Bath Ankylosing Spondylitis Disease Activity Index (BASDAI). Low disease activity was determined based on a BASDAI score of <3.0. In the group of patients with PSA, disease activity was established based on the number of tender joints (for 68 joints) and swollen joints (for 66 joints), spinal pain VAS and BASDAI scores, and a general assessment of disease activity (according to the patients and their physicians) on a 5-point Likert scale. Low disease activity is defined as a $50 \%$ reduction in the values of the assessed parameters (the number of tender and swollen joints, disease activity according to the patient and physician on the Likert scale), or a BASDAI score $<3.0$.

Patients with RA were eligible for ADA therapy if they fulfilled current Polish National Health Fund (NFZ) therapeutic programme criteria [18], i.e. cases with an aggressive disease course (DAS28 > 5.1 measured twice, with a one-month interval between assessments) and failure of treatment using $\geq 2$ traditional DMARDs (including the maximum dose of MTX), with each drug being administered over a period $\geq 6$ months. All the RA patients had undergone prior treatment with several DMARDs, including, in every case, MTX as well as sulfasalazine (SS), chloroquine (CQ), leflunomide (LEF), cyclosporine A (CSA), gold salts, the product Cuprenil, azathioprine, cyclophosphamide (CYC), and biological drugs: etanercept (ETA) (8 patients), 
infliximab (IFX) (4 patients), and the anti-interleukin-6 receptor antibody (IL-6R) (1 patient).

Patients with AS were qualified for ADA therapy if they had active and severe disease (BASDAI $\geq 4$ and spinal VAS $\geq 4$ ), documented twice, with an interval $\geq 12$ weeks between assessments, in the absence of a satisfactory response to $\geq 2$ non-steroid anti-inflammatory drugs (NSAIDs) [18]. All the AS patients had undergone prior treatment with DMARDs (MTX, SS, LEF, CYC) and biological drugs: IFX (2 patients) and ETA (1 patient). Patients with AS had signs of peripheral joint involvement (4 patients) and non-articular features (6 patients) (cardiological manifestations, amyloidosis, iritis, Crohn's disease).

Patients with PSA qualified to receive ADA therapy if they had active and severe forms of PSA, documented in the course of two separate appointments, with an interval of $\geq 4$ weeks, in the absence of any effect of disease-modifying treatment [18]. All the patients with PSA had undergone prior treatment with DMARDs (MTX, SS, LEF); 2 patients had previously received anti-TNF agents (ETA, IFX). All of the patients were found to have peripheral joint inflammation, signs of axial involvement were present in 2 patients, two had enthesitis and one patient had dactylitis.

Adalimumab was administered in accordance with NFZ therapeutic programme recommendations, as second-line treatment or initiation therapy in biological treatment. ADA was administered subcutaneously, at a dose of $40 \mathrm{mg} /$ 2 weeks. The monitoring of treatment effectiveness and safety was conducted in accordance with the principles of the NFZ therapeutic programme [18].

Statistical analysis was performed using the Statistica 10 program. Results were presented as mean values (standard deviation) or numbers (\%). The fraction test was used to evaluate inter-group differences in therapeutic response between groups of patients with RA and AS.

\section{Results}

The characteristics of patients treated with ADA are presented in Table I.

Table I. Characteristics of patients and results of treatment with adalimumab

\begin{tabular}{|c|c|c|c|}
\hline Patients/Data & RA & AS & PSA \\
\hline Number (F/M) & $24(16 / 8)$ & $11(9 / 2)$ & $6(3 / 3)$ \\
\hline Age [in years (SD)] & $53.4(12.5)$ & $41.3(9.1)$ & $48.2(13.7)$ \\
\hline $\begin{array}{l}\text { Duration of the disease at ADA } \\
\text { treatment initiation [in years (SD)] }\end{array}$ & $9.1(5.5)$ & $5.2(4.8)$ & $7.8(6.8)$ \\
\hline RF-IgM positive (n/\%) & $15(62.5 \%)$ & - & $1(16.7 \%)$ \\
\hline ACPA positive ( $n / \%)$ & 19 (79.2\%) & - & $2(33.3 \%)$ \\
\hline ANA positive $(n / \%)$ & $7(29.2 \%)$ & $2(18.2 \%)$ & 0 \\
\hline HLA-B27 positive $(n / \%)$ & - & $8(72.7 \%)$ & $2(33.3 \%)$ \\
\hline Duration of treatment with ADA [in months (SD)] & $\begin{array}{l}16.2(16.9) \\
(3-83)\end{array}$ & $\begin{array}{c}17.5(8.1) \\
(4-33)\end{array}$ & $\begin{array}{c}11.8(4.1) \\
(5-15)\end{array}$ \\
\hline \multirow[t]{2}{*}{ Primary failure (n/\%) } & $\begin{array}{l}4(16.7 \%) \\
\text { after } 3 \mathrm{mo} .\end{array}$ & $1(9.1 \%)$ & $1(16.7 \%)$ \\
\hline & $\begin{array}{l}10(41.7 \%) \\
\text { after } 6 \text { mo. }\end{array}$ & & \\
\hline $\begin{array}{l}\text { Duration of ADA drug-free remission } \\
\text { [in months (SD)] }\end{array}$ & $\begin{array}{l}4.6(2.3) \\
(2-7)\end{array}$ & $\begin{array}{c}5.4(2.6) \\
(3-11)\end{array}$ & \\
\hline $\begin{array}{l}\text { Flare following remission/low disease } \\
\text { activity }(n / \%)\end{array}$ & $6 / 13(46.2 \%)$ & $8 / 10(80 \%)$ & - \\
\hline Secondary failure $(n / \%)$ & $2 / 13(15.4 \%)$ & $1 / 10(10 \%)$ & - \\
\hline Adverse effects of ADA therapy $(n / \%)$ & $10 / 24(41.7 \%)$ & 6/11 (54.5\%) & $1(16.7 \%)$ \\
\hline Discontinued due to adverse effects ( $n / \%)$ & $4 / 24(16.7 \%)$ & 1/11 (9.1\%) & - \\
\hline
\end{tabular}

ACPA - anti-citrullinated peptide/protein antibodies, ADA - adalimumab, ANA - anti-nuclear antibodies, RF-IgM - rheumatoid factor, SD - standard deviation 


\section{Results of treatment in patients with rheumatoid arthritis}

ADA was administered as monotherapy in 4 patients (16.7\%) and the remainder received ADA combined with classic DMARDs: MTX (45.8\%), CQ (29.2\%), CSA (12.5\%), LEF (8.3\%), SS (4.2\%), and glucocorticosteroids (GCS) (91.7\%). Patients were treated with ADA for a mean period of 16 months (Table I). As a result of the therapy, 13 patients (54.2\%) achieved an adequate response to treatment, of which 8 subjects (33.3\%) achieved remission, and 5 (20.9\%) achieved low disease activity. Primary lack of efficacy was observed in 4 patients (16.7\%) after 3 months of therapy (lack of adequate response - subjects did not achieve a decrease in DAS28 > 1.2) and in a total of 10 patients (41.7\%) after 6 months (subjects did not achieve remission or low disease activity). The effects of treatment remain unclear in one patient, because after approximately one month of ADA therapy this patient experienced a myocardial infarction with fatal outcome.

In accordance with NFZ therapeutic programme guidelines, treatment with ADA was withdrawn in periods of sustained remission/low disease activity. A good response to treatment was observed over a mean period of 9.8 months (3-20 months). Five patients had sustained remission/low disease activity without ADA therapy over a mean period of 4.6 months (Table I). None of the patients had permanent ADA drug-free remission, sustained over 12 months.

Six out of 13 patients in remission or with low disease activity experienced an increase in RA activity. In the event of a flare, ADA was restarted or the DMARD therapy was adjusted (1 patient received concomitant MTX; 2 patients received an increased dose of $M T X)$, which resulted in 4 patients again achieving a good response to treatment after 2-3 months. Two patients did not show any improvement and had secondary failure. Treatment with ADA was discontinued in the course of remission in 2 patients, because of significant adverse events (skin lesions at the site of injection). One patient remains in remission and a second is receiving alternative anti-TNF treatment because of RA flares.

\section{Results of treatment in patients with ankylosing spondylitis}

ADA was administered as monotherapy in 5 patients (45.5\%), and the remainder received ADA combined with classic DMARDs: MTX (45.5\%), CSA (9.1\%), SS (9.1\%); GCS in $54.5 \%$; and NSAIDs in $81.8 \%$. Two patients did not receive NSAIDs due to adverse effects (gastric mucosal inflammation, leucopenia). Ten patients (90.9\%) achieved an adequate response to treatment after 12 weeks (reduction in BASDAI by $\geq 50 \%$ or by 2 units and a reduction in spinal pain VAS by $\geq 2 \mathrm{~cm}$ ); one patient lacked an adequate response to treatment (Table I). In accordance with NFZ therapeutic programme guidelines, in the event of low disease activity, treatment using ADA was continued for 6 months and then withdrawn. Patients sustained low disease activity without ADA therapy over a mean period of 5.4 months (Table I). ADA therapy was discontinued in 1 patient in a period of low activity due to significant adverse effects (skin lesions at the site of injection), and treatment was continued with another anti-TNF agent. Following ADA therapy discontinuation, 8 patients (80\%) experienced AS flares. In such cases, ADA treatment was restarted and adjustments were made in DMARD therapy (1 patient received an increased dose of $M T X$ ), resulting in a return to low disease activity in 6 patients. One patient did not respond (secondary failure), and one patient did not resume ADA therapy because of depression.

\section{Results of treatment in patients with psoriatic arthritis}

All the patients were treated with ADA combined with classic DMARDs: MTX (66.7\%), SS (33.3\%), and CSA (16.7\%). Adequate response after 12 weeks of treatment (in cases of peripheral joint involvement, a reduction of $\geq 30 \%$ in the number of tender and swollen joints and the Likert score; in the case of spinal involvement, a reduction in BASDAl by $\geq 50 \%$ or by 2 units) was present in 5 patients (83.3\%) with continued ADA therapy; one patient lacked an adequate response (Table I). In view of the short duration of the NFZ therapeutic programme, patients continue to receive ADA with ongoing assessment of the effects of the therapy.

\section{Comparison of treatment results in patients with rheumatoid arthritis and with ankylosing spondylitis}

The statistical analysis revealed that the number of adequate responses to treatment was statistically significantly higher in the group of patients with AS compared with patients with RA [10 (90.9\%) vs. 13 (54.2\%), respectively, $p=0.04]$. There were no significant differences in the duration of ADA drug-free remissions between patients with AS and RA. The group of patients with RA was statistically significantly older than patients with AS [53.4 (12.5) vs. 41.3 (9.1) years, $p=0.007]$.

\section{Adverse effects of adalimumab treatment}

Among 41 patients treated with ADA, adverse effects were observed in 17 (41.5\%). The most common were symptoms of infection, namely: urinary tract infections (5 patients), respiratory tract infections (2 patients), recurrent herpes (1 patient), and cytomegalovirus infection (1 patient). Six patients had skin reactions at the site of injec- 
tion. During the course of treatment, one patient experienced subarachnoid haemorrhage secondary to cerebral aneurysm (treatment with ADA was resumed after being suspended, with good effect); one patient experienced a myocardial infarction with fatal outcome approximately one month after initiation of ADA therapy. Adverse effects led to discontinuation of ADA treatment in 5 patients 4 patients had skin symptoms ( 3 patients with RA and one with AS) and one patient with RA had recurring urinary tract infections.

\section{Discussion}

The authors analysed the results of adalimumab treatment in patients with RA, AS, and PSA, conducted in an NFZ therapeutic programme, i.e. routine clinical practice. Signs of clinical remission were observed in the majority of patients. Improvement was rapid and generally observed within 1-3 months of treatment. The highest percentage of adequate responses was recorded among patients with AS; the percentage of subjects with a lack of adequate response was highest in patients with RA. The difference in the number of adequate responses to treatment among patients with AS and RA was statistically significant. The inadequate response to therapy in patients with RA qualified to receive treatment with ADA may be due to the fact that this group had more advanced disease and the patients were older. All the patients with RA had been treated earlier with at least two, and most often several traditional DMARDs, GCS, as well as biological DMARDs, with no satisfactory effect.

Time to remission was shortest in patients with AS. While in clinical remission, following discontinuation of treatment with ADA, some patients experienced flares of disease activity, which occurred most frequently in the AS group. This necessitated adjustments in therapy a resumption of treatment with ADA or an increase in the MTX dosage (recommended and effective particularly in RA), and the majority of patients achieved disease remission again. In isolated cases, adverse events resulted in discontinuation of ADA treatment.

The results of this study are consistent with published data, which emphasise that ADA acts rapidly, effectively and produces permanent RA, AS, and PSA activity inhibition. However, most reports originate from clinical studies $[2,4,5,8,9,11]$ and only isolated, recently published papers refer to groups of patients treated in a routine practice setting $[7,13,14]$. This paper presents the results of treatment with ADA in routine clinical practice, comparing the course and effects of the therapy in groups of patients with RA, AS, and PSA. The results confirm the effectiveness of this treatment and may serve as encouragement for further, long-term studies.

\section{Conclusions}

In routine clinical practice, treatment with ADA is an effective and safe form of therapy in patients with RA, AS, and PSA with persistently high disease activity, nonresponsive to previously administered types of therapy.

The author declares no conflict of interest and no funding.

\section{References}

1. Burmester GR, Panaccione R, Gordon KB, et al. Adalimumab: longterm safety in 23458 patients from global clinical trials in rheumatoid arthritis, juvenile idiopathic arthritis, ankylosing spondylitis, psoriatic arthritis, psoriasis and Crohn's disease. Ann Rheum Dis 2012 doi:10.1136/annrheumdis-2011-201244.

2. Poddubnyy D, Rudwaleit M. Efficacy and safety of adalimumab treatment in patients with rheumatoid arthritis, ankylosing spondylitis and psoriatic arthritis. Expert Opin Drug Saf 2011; 10: 655-673.

3. Rudwaleit M, Van den Bosch F, Kron M, et al. Effectiveness and safety of adalimumab in patients with ankylosing spondylitis or psoriatic arthritis and history of anti-tumor necrosis factor therapy. Arthritis Res Ther 2010; 12: R117.

4. Burmester GR, Mariette X, Montecucco C, et al. Adalimumab alone and in combination with disease-modifying antirheumatic drugs for the treatment of rheumatoid arthritis in clinical practice: the Research in Active Rheumatoid Arthritis (ReAct) trial. Ann Rheum Dis 2007; 66: 732-739.

5. Weinblatt ME, Keystone EC, Furst DE, et al. Long term efficacy and safety of adalimumab plus methotrexate in patients with rheumatoid arthritis: ARMADA 4 year extended study. Ann Rheum Dis 2006; 65: 753-759.

6. Bombardieri S, Ruiz AA, Fardellone P, et al. Effectiveness of adalimumab for rheumatoid arthritis in patients with a history of TNFantagonist therapy in clinical practice. Rheumatology (Oxford) 2007; 46: 1191-1199.

7. Hjardem E, Ostergaard M, Podenphant J, et al. Do rheumatoid arthritis patients in clinical practice benefit from switching from infliximab to a second tumor necrosis factor alpha inhibitor? Ann Rheum Dis 2007; 66: 1184-1189.

8. Van der Heijde D, Breedveld FC, Kavanaugh A, et al. Disease activity, physical function, and radiographic progression after longterm therapy with adalimumab plus methotrexate: 5 -year results of PREMIER. J Rheumatol 2010; 37: 2237-2246.

9. Revicki DA, Luo MP, Wordsworth $P$, et al. Adalimumab reduces pain, fatigue, and stiffness in patients with ankylosing spondylitis: results from the adalimumab trial evaluating long-term safety and efficacy for ankylosing spondylitis (ATLAS). J Rheumatol 2008; 35: 1346-1353.

10. Rudwaleit M, Claudepierre P, Kron M, et al. Effectiveness of adalimumab in treating patients with ankylosing spondylitis associated with enthesitis and peripheral arthritis. Arthritis Res Ther 2010; 12: R43.

11. Mease PJ, Ory P, Sharp JT, et al. Adalimumab for long-term treatment of psoriatic arthritis: 2-year data from the Adalimumab Effectiveness in Psoriatic Arthritis Trial (ADEPT). Ann Rheum Dis 2009; 68: 702-709. 
12. Rudwaleit M, Van den Bosch F, Kron M, et al. Effectiveness and safety of adalimumab in patients with ankylosing spondylitis or psoriatic arthritis and history of anti-tumor necrosis factor therapy. Arthritis Res Ther 2010; 12: R117.

13. Paccou J, Baclé-Boutry MA, Solau-Gervais E, et al. Dosage Adjustment of Anti-Tumor Necrosis Factor- $\alpha$ Inhibitor in Ankylosing Spondylitis Is Effective in Maintaining Remission in Clinical Practice. J Rheumatol 2012; 39: 1418-1423.

14. Ornbjerg LM, Ostergaard $M$, Bøyesen $P$, et al. Impact of tumour necrosis factor inhibitor treatment on radiographic progression in rheumatoid arthritis patients in clinical practice: results from the nationwide Danish DANBIO registry. Ann Rheum Dis 2012 doi:10.1136/annrheumdis-2012-201319.

15. Arnett FC, Edworthy SM, Bloch DA, et al. The American Rheumatism Association 1987 revised criteria for the classification of rheumatoid arthritis. Arthritis Rheum 1988; 31: 315- 324.

16. Van der Linden S, Valkenburg HA, Cats A. Evaluation of diagnostic criteria for ankylosing spondylitis. A proposal for modification of the New York criteria. Arthritis Rheum 1984; 27: 361-368.

17. Taylor W, Gladman D, Helliwell P, et al. Classification criteria for psoriatic arthritis: development of new criteria from a large international study. Arthritis Rheum 2006; 54: 2665-2673.

18. Programy lekowe. Obwieszczenie Ministra Zdrowia z dnia 28 czerwca 2012 r. w sprawie wykazu refundowanych leków, środków spożywczych specjalnego przeznaczenia żywieniowego oraz wyrobów medycznych na dzień 1 lipca 2012 r. (załączniki: B.33, B.35, B.36). 